\title{
The Effects of 1-Methylcyclopropane (1-MCP) and MAP treatments on Quality Parameters of "Hicaz" Pomegranate Cultivar
}

\author{
Fatih Cem Kuzucu*, Mustafa Sakaldaş, Tolga Sarıer \\ Department Of Horticulture, Faculty Of Agriculture, Çanakkale Onsekiz Mart University, 17100 Çanakkale, Turkey
}

\section{A R T I C LE IN F O}

\section{Research Articles}

Received 07 March 2017

Accepted 05 April 2017

\section{Keywords:}

Hicaz pomegranate

1-Methylcyclopropane

MAP

Preservation

Quality

*Corresponding Author:

E-mail: fatihcem2005@hotmail.com

\begin{abstract}
A B S T R A C T
Pomegranate has been recently considered as a significant fruit for human health and demanded year-long apart from two-month standard harvest period. To extend market supply durations over longer periods, various methods and treatments should be applied to pomegranates to preserve quality parameters throughout different storage durations. The present study was conducted at cold storages of ÇOMÜ Agricultural Faculty to investigate the effects of 1-Methylcyclopropane (1-MCP) and MAP (LDPE, $20 \mathrm{m \mu}$ ) treatments on quality attributes of 'Hicaz' pomegranate cultivar. Experimental materials were treated with two different doses $(625$ and $1250 \mathrm{ppb})$ of 1-MCP alone and combined with MAP (625 ppb + MAP and $1250 \mathrm{ppb}+\mathrm{MAP})$ and stored at 3 different storage durations (40, 80 and 120 days). All fruits, including control group, were stored at 6.5$7.5^{\circ} \mathrm{C}$ temperature and $85-90 \%$ relative humidity. At the end of each storage period, fruits were subjected to weight loss (\%), Total soluble solids (TSS) content (\%), titratable total acidity (TTA) $(\% \mathrm{~g}), \mathrm{pH}$, grain color (a value), decay ratio $(\%)$ analyses and assessments were performed for these quality and biochemical characteristics. Both Doses of 1-MCP alone and combined with MAP treatments were found to be more efficient in decelerating the adverse effects on rotting, perishes and other quality parameters, however there were not significant differences between two doses of 1-MCP. Therefore, MAP or $625 \mathrm{ppb} 1$ MCP treatments alone or combined with MAP treatments can be recommended for better preservation of quality parameter throughout the storage of pomegranates.
\end{abstract}

\section{1-Methylcyclopropane (1-MCP) ve MAP Uygulamalarının "Hicaz" Nar Çeşidinde Meyve Kalitesine Etkileri}

M A K A L E B İ L G İ S İ

\section{Araştırma Makalesi}

Geliş 07 Mart 2017

Kabul 05 Nisan 2017

Anahtar Kelimeler:

Hicaz

1-Methylcyclopropane

MAP

Muhafaza

Kalite

*Sorumlu Yazar:

E-mail: fatihcem2005@ hotmail.com

\section{Ö Z E T}

Nar, son yıllarda insan sağlığı için önemli meyveler grubu içerisinde değerlendirilmeye başlanmış, iki aylık standart hasat zamanı dışında da tüketici tarafından yıl boyunca talep edilir hale gelmiş bir meyvedir. Piyasaya meyve arzının daha uzun bir periyoda yayılabilmesi için narın muhafazasında çeşitli yöntemler ve uygulamalar yapılması gerekmektedir. Bu amaçla 1-Methylcyclopropane (1-MCP) ve MAP (LDPE, $20 \mathrm{m \mu}$ ) uygulamalarının etkilerini belirlemek için "Hicaz" nar çeşidi dikkate alınarak yapılan çalışma Ç.O.M.Ü. Ziraat Fakültesi soğuk hava depolarında yürütülmüştür. Araştırmada nar meyveleri, 1- MCP'nin iki farklı dozu (625 ve $1250 \mathrm{ppb})$ tek başına ve ayrıca MAP ile kombine edilmiş (625 ppb + MAP ve $1250 \mathrm{ppb}+\mathrm{MAP})$ şekilde olmak üzere, 3 farklı muhafaza süresince $(40,80,120$ gün) depolamaya alınmışlardır. Araştırma süresince kontrol grubu dahil tüm meyveler $6,5-7,5^{\circ} \mathrm{C}$ sıcaklık ve \%85-90 oransal nem koşullarında muhafazaya alınmıştır. Depolama periyotları sonunda uygulamalar; ağırlık kaybı (\%), SÇKM (\%), TETA $(\% \mathrm{~g}), \mathrm{pH}$, tane rengi (a değeri), çürüme-bozulma oranı (\%) gibi kalite ve biyokimyasal özellikleri ifade eden özellikler bakınından değerlendirilmiştir. Değerlendirme sonuçlarına göre 1-MCP'nin her iki dozununda tek başına ya da MAP ile kombine edilerek uygulanması meyvelerde çürüme, bozulma ve diğer kalite parametrelerindeki olumsuz gelişmeleri yavaşlatmada daha etkili olduğu belirlenmiş, ancak 1-MCP'nin iki dozu arasında önemli bir fark bulunamamıştır. Bu nedenle nar muhafazasında kalite özelliklerinin daha iyi muhafazası için MAP ve ya 625 ppb 1MCP'nin tek başına ya da MAP ile kombine edilerek kullanılması önerilebilir. 


\section{Introduction}

Pomegranate is native to a region from Iran to northern India and has been cultivated throughout the Middle East, South Asia, and Mediterranean region for several millennia. Pomegranates are cultivated over coastal and mountainous sections of Turkey and quite widespread in Aegean, Mediterranean and Southeast Anatolia regions. The cultivation in Southeast Anatolia region increased with SAP project. Hicaz, Çekirdeksiz 6, Silifke aşısı, Katırbaşı and Lefan are the most common cultivars grown in Turkey. Hicaz has the first place among the imported pomegranate cultivars (Özgüven and Yilmaz, 2000).

Pomegranade seeds contain $79 \%$ water, $18 \%$ carbohydrate, $1.1 \%$ protein and $0.9 \%$ oil and $100 \mathrm{~g}$ seeds provide $70 \mathrm{kcal}$ energy (Anonymous, 2013).

Modified atmosphere packaging (MAP) is a technology that has been developed to ensure that packaged food products stay fresh and attractive for as long as possible. It is a technology in which the package is filled with a certain gas mixture instead of air (Sivertsvik et al., 2002).

MAP is a low density polyethylene package with high $\mathrm{CO}_{2}$ and $\mathrm{O}_{2}$ permeability. The package has relatively high $\mathrm{CO}_{2}$ formation rates and low $\mathrm{O}_{2}$ concentrations. In other words, while decreasing $\mathrm{O}_{2}$ concentrations are allowed, quite excessive $\mathrm{CO}_{2}$ concentrations are allowed in these packages. Some PVC films with quite high $\mathrm{CO}_{2} / \mathrm{O}_{2}$ permeability are good for MAP (Kader et al., 1986).

There are several substances used to control ethylene receptors. Among them, 2,5-NBD and trans-cyclooctene are known with their detrimental impacts and unpleasant smells and DACP is known with explosive characteristics. However, 1-MCP is odorless and there is no evidence for toxicity. Therefore, it can reliably be selected as an ethylene inhibitor (Sisler and Serek, 1999).

Slight mutagenity and cancerogenic effects on rodents were mentioned for some doses of 1-MCP (Renwick et al., 2010).

Cyclopropene (CP), 1-methylcyclopropene (1-MCP) and 3,3-dimethylcyclopropene (3,3-DMCP) are used for ethylene inhibition in several plants. These substances are also used to prolong shelf life of cut-flowers (Sisler and Serek, 1997).

1-MCP exists in solid formulation and transforms into gas formulation in an hour when contacted with water based on temperature and other conditions. After 6-24 hours, the product can be transferred to air or controlled atmosphere conditions. 1-MCP is a safe substance without any residues and can be used in either small or large product groups. Ethylene molecules are tied to ethylene receptors and leave the receptors when the chemical signal was transmitted to the cell. When the 1MCP is tied to ethylene receptors, the message is not transmitted to the cell. At the same time, 1-MCP doesn't leave the receptor and thus ethylene molecules are not tied to receptor (Blankenship, 2001).

Physiological impacts of ethylene can be prevented with inhibitors or antagonists of ethylene biosynthesis. AVG (aminoethoxy-vinilyglycine) and AOA (aminooxiacetic acid) inhibits ethylene synthesis; MCP, carbon dioxide, silver ions and trans-cyclooctyone prevents the effects of ethylene. Silver $\left(\mathrm{Ag}^{+}\right)$is commonly used to prolong the shelf life of cut carnations. AVG retards flower wilting and fruit ripening (Taiz and Zeiger, 2008).

Nanda et al. (2001) conducted a study to investigate the effects of two polyolefin shrink film (BDF-2001 and D-955) and sucrose polyester surface coating (SPE) Semperfresh $^{\mathrm{TM}}$ treatments on shelf life and quality of 'Ganesh' pomegranates (Punica granatum L.). It was observed at $8,15,25^{\circ} \mathrm{C}$ temperatures that shrink coated pomegranates were able to be stored respectively for 12 , 9, 4 weeks, sucrose polyester coated pomegranates for 8 , 6, 2 weeks and uncoated ones for 7, 5, 1 weeks. Shrink film coating preserved peel thickness, freshness and firmness and weight loss was greatly reduced. While the weight loss in shrink coating treatments at the end of 12 weeks at $8^{\circ} \mathrm{C}$ was $1.2-1.3 \%$, the value in uncoated fruits was $20.4 \%$; again while the weight loss at the end of 10 week at $15^{\circ} \mathrm{C}$ was $2.2-3.7 \%$, the value in uncoated ones was $30.7 \%$.

Artes et al. (2000) carried out a study to investigate the post-harvest heat treatments on shelf life and quality of pomegranates (Punica granatum L. cv Mollar de Elche). Researchers stored control fruits at 2 and $5^{\circ} \mathrm{C}$ for 90 days; fruits in intermittent heat treatment were stored at 2 or $5^{\circ} \mathrm{C}$ for 6 days, then stored at $20^{\circ} \mathrm{C}$ for a day and storage at 2 or $5^{\circ} \mathrm{C}$ went on; fruits in curing treatment were stored at 2 or $5^{\circ} \mathrm{C}$ for 6 days, then stored at $33^{\circ} \mathrm{C}$ for 3 days and storage at 2 or $5^{\circ} \mathrm{C}$ went on, and all treatments were finally subjected to shelf-life treatment at $15^{\circ} \mathrm{C}$ for 6 days. Brix values increased with curing + shelf life treatment and did not significantly change with the other treatments; aroma decreased in all treatments except for $5^{\circ} \mathrm{C}$ heat treatment; $5^{\circ} \mathrm{C}$ heat and curing treatment had the least aroma value; aroma values did not change with $2^{\circ} \mathrm{C}$ heat and intermittent heat treatment; significant weight loss was observed in all treatments as compared to control treatment; the greatest weight loss was observed in 2 or $5^{\circ} \mathrm{C}$ heat treatments and intermittent heat treatment.

Kader et al. (1984) investigated the response of pomegranates to ethylene treatments and storage temperatures and reported that ethylene treatments did not have significant effects on peel color, fruit juice color, soluble solids content, $\mathrm{pH}$ and titratable acidity values. Fruits were stored at $0,2.2,5$ and $10^{\circ} \mathrm{C}$ for $4,8,12$ and 16 weeks and increasing weight losses and decreasing titratable acidity values were observed at all storage durations and temperatures. While soluble solids content did not change at 0 and $10^{\circ} \mathrm{C}$ storage temperatures for 4 weeks, the value decreased in all the other storage durations and temperatures. Also, $\mathrm{pH}$ values slightly decreased at $10^{\circ} \mathrm{C}$ storage temperature for 4 weeks, but increased in all the other storage durations and temperatures.

Yazıc1 et al. (2005) carried out a study to investigate the effects of modified atmosphere and kaolin treatments on preservation of "Hicaz" pomegranates and treated fruits with Kaolin (3\% pre-harvest 4 times and $6 \%$ postharvest), Kaolin+MA and MA. Fruits were stored for 180 
days and subjected to analyses in every 45 days. Weight loss increased throughout the storage in all treatments and the greatest weight loss was observed in Kaolin+MA and MA treatments; soluble solids content increased until $90^{\text {th }}$ day in all treatments, decreased then and the greatest soluble solids content was observed in Kaolin treatments; titratable acidity decreased in all treatments throughout the storage and the least acidity was observed in Kaolin treatments; peel thickness increased until $90^{\text {th }}$ day in all treatments, decreased then and the lowest value was seen in Kaolin treatment. It was concluded that Hicaz pomegranates could be preserved for 6 months with Kaolin+MA and MA treatments without significant losses in quality parameters.

The aim of this study is; to increase the storage period of the "Hicaz" pomegranate fruits without disrupting the quality characteristics of the fruit, to provide a longer fruit supply to the market and to make producers more economically viable production.

\section{Material and Method}

'Hicaz' pomegranate fruits were used as the plant material of this study. Fruits were harvested from producer orchards at traditional harvest date and the ones without any damages over the surfaces and any symptoms of disease were selected to form experimental treatment groups. For experimental treatments, $20 \mathrm{~m} \mu$ semipermeable low-density polyethylene (LDPE) was used as modified atmosphere packaging (MAP) material and Smartfresh $^{\mathrm{TM}}$ brand chemical substance supplied by Rohm and Haas Corporation was used in 1Methylcyclopropane (1-MCP) treatments.

Control group was not subjected to any treatments. Another group was subjected to $625 \mathrm{ppb}$ and $1250 \mathrm{ppb} 1$ MCP doses for 24 hours. Half of treated fruits were placed in open plastic boxes and the other half were combined with MAP (LDPE, $20 \mathrm{~m} \mu$ ) packages. All fruits were stored at $6.5-7.5^{\circ} \mathrm{C}$ temperature and $85-90 \%$ relative humidity for 40, 80 and 120 days.

At the end of each storage period, fruits were subjected to following analyses:

Weight loss (\%): Fruits were weighed with a precise scale (Sartorius) ( $\pm 0.01 \mathrm{~g})$ to determine weight losses throughout the storage duration. Weight losses were expressed in \% with the following equation;

\section{[(Initial weight - Final weight $) /$ Initial weight $] \times 100$}

Total soluble solids: TSS contents were measured with a digital refractometer and expressed in $\%$.

Titratable total acidity (TTA) (\%g): TTA values were determined through titration with $0.1 \mathrm{~N} \mathrm{NaOH}$. Orlab digital burette and WTW digital bench-type $\mathrm{pH}$ meter were used in measurements. The amount of $\mathrm{NaOH}$ consumed in titration to increase $\mathrm{pH}$ of fruit extract to 8.1 was expressed in citric acid equivalent $(\mathrm{g} / 100 \mathrm{~g})$ (Karaçalı, 2009).

$p H$ : WTW series Inolab digital $\mathrm{pH}$ meter was used to measure the $\mathrm{pH}$ of fruit juice.
Grain color (a value): Color parameters ( $\mathrm{L}$, a and b) were measured with Minolta CR-40 Colorimeter. L is an indicator of whiteness-blackness and varies between 0 (black) and 100 (white); a is an indicator of greennessredness and varies between -60 (green) and +60 (red); $b$ is an indicator of blueness-yellowness and varies between 60 (blue) and +60 (yellow) (Özdemir, 2001). For pomegranates, a value should be considered in grain color measurements.

Decay ratio (\%): The perished and rotten fruits due to fungal or bacterial factors were counted and proportioned to the initial number of fruits in replication.

\section{Statistical Analysis}

Descriptive statistics for the studied variables (characteristics) were presented as mean, standard deviation, minimum and maximum values. One way ANOVA test was used to compare groups. Following the ANOVA, Duncan multiple comparison test was used to determine different groups. Statistical significance level was considered as 5\% and MINITAB (ver: 15) statistical program was used for all statistical computations.

\section{Results and Discussion}

Weight loss: Weight loss measurements (Figure 1) clearly revealed the positive impacts of MAP treatments on water loss in fruits. Weight loss values were quite low in MAP and combined 1-MCP + MAP treatments. Increasing water loss is an expected outcome with the progress of storage duration. MAP and combined 1-MCP + MAP treatments yielded the lowest weight loss values especially for 80-day storage period and the differences between the experimental groups were found to be significant (Table 1). With regard to weight loss, MAP treatments were found to be significant for 80-day storage and $625 \mathrm{ppb}+\mathrm{MAP}$ and $1250 \mathrm{ppb}+$ MAP treatments were found to be significant for 120-day storage. Similar to control treatments, 1-MCP-treated but unpacked fruits had also quite high weight loss levels. Current findings on weight loss values comply with the results of Nanda et al. (2001).

Total soluble solids (TSS): Total soluble solids content is an indicator of sugar components of the fruits and different storage durations and treatments resulted in fluctuations in dry matter composition of the fruits (Figure 2 and Table 2) While 1250ppb 1-MCP + MAP and MAP treatments yielded the greatest values during the initial stage of duration (40-day), significant decreases were observed in these treatments with the progress of storage duration. Especially MAP treatments had a remarkable value at the end of 120-day storage. For the second stage storage (80-day), values increased in control, $625 \mathrm{ppb} 1-\mathrm{MCP}$ and $1250 \mathrm{ppb}+\mathrm{MAP}$ treatments, but the values in the same treatments had sudden decreases in 120-day storage. Such a case created a suspicion about metabolic status of the fruits. The 625ppb 1-MCP + MAP and $1250 \mathrm{ppb} 1-\mathrm{MCP}$ treatments best preserved TSS composition of the fruits throughout the storage periods. 
Table 1 Effects of application and storage periods on weight loss (\%)

\begin{tabular}{|c|c|c|c|c|c|}
\hline \multirow{2}{*}{ Aplications } & \multicolumn{4}{|c|}{ Storage Periods } & \multirow{2}{*}{$\begin{array}{c}\text { Application } \\
\text { means }\end{array}$} \\
\hline & Harvest & 40 days & 80 days & 120 days & \\
\hline Control & 0 & $9.64^{\mathrm{c}}$ & $11.74^{\mathrm{b}}$ & $7.22^{\mathrm{c}}$ & $9.53^{C}$ \\
\hline $625 \mathrm{ppb} 1-\mathrm{MCP}$ & 0 & $12.32^{\mathrm{ab}}$ & $12.94^{\mathrm{a}}$ & $12.81^{\mathrm{a}}$ & $12.69^{\mathrm{A}}$ \\
\hline $1250 \mathrm{ppb} 1-\mathrm{MCP}$ & 0 & $9.35^{\mathrm{c}}$ & $8.27^{\mathrm{d}}$ & $12.79^{\mathrm{a}}$ & $10.13^{\mathrm{B}}$ \\
\hline MAP & 0 & $5.25^{\mathrm{f}}$ & $1.30^{\mathrm{i}}$ & $3.27^{\text {gh }}$ & $3.27^{\mathrm{D}}$ \\
\hline $625 \mathrm{ppb} 1-\mathrm{MCP}+\mathrm{MAP}$ & 0 & $4.77^{\mathrm{f}}$ & $1.83^{\mathrm{i}}$ & $2.89^{\mathrm{h}}$ & $3.16^{\mathrm{DE}}$ \\
\hline $1250 \mathrm{ppb} 1-\mathrm{MCP}+\mathrm{MAP}$ & 0 & $3.81^{\mathrm{g}}$ & $1.87^{\mathrm{i}}$ & $2.87^{\mathrm{h}}$ & $2.85^{\mathrm{E}}$ \\
\hline Storage Period means & 0 & $7.52^{\mathrm{A}}$ & $6.32^{\mathrm{C}}$ & $6.97^{\mathrm{B}}$ & \\
\hline $\begin{array}{l}\text { LSD }(\mathrm{P}<0.05) \\
\text { LSD }_{\text {Int }}(\mathrm{P}<0.05)\end{array}$ & \multicolumn{4}{|c|}{$\begin{array}{l}0.0344 \\
0.6402\end{array}$} & 0.3952 \\
\hline
\end{tabular}

Values in the same column and raw followed by different small and capital letters are significantly different $(\mathrm{P}<0.05)$ by LSD., N.S.: Not significant.

Table 2 Effects of application and storage periods on grain color (a value)

\begin{tabular}{|c|c|c|c|c|c|}
\hline \multirow{2}{*}{ Aplications } & \multicolumn{4}{|c|}{ Storage Periods } & \multirow{2}{*}{$\begin{array}{c}\text { Application } \\
\text { means }\end{array}$} \\
\hline & Harvest & 40 days & 80 days & 120 days & \\
\hline Control & 18.87 & $16.55^{\mathrm{de}}$ & $16.11^{\mathrm{ef}}$ & $15.23^{\mathrm{g}}$ & $15.96^{\mathrm{d}}$ \\
\hline 625 ppb 1-MCP & 18.87 & $19.58^{\mathrm{a}}$ & $17.45^{\mathrm{bc}}$ & $16.99^{\mathrm{bcd}}$ & $18.00^{\mathrm{a}}$ \\
\hline $1250 \mathrm{ppb} 1-\mathrm{MCP}$ & 18.87 & $17.85^{\mathrm{b}}$ & $16.92^{\text {cde }}$ & $15.27^{\mathrm{fg}}$ & $16.68^{\mathrm{c}}$ \\
\hline MAP & 18.87 & $18.79^{\mathrm{a}}$ & $17.54^{\mathrm{bc}}$ & $17.05^{\mathrm{bcd}}$ & $17.79^{\mathrm{a}}$ \\
\hline $625 \mathrm{ppb} 1-\mathrm{MCP}+\mathrm{MAP}$ & 18.87 & $18.92^{\mathrm{a}}$ & $17.34^{\text {bcd }}$ & $17.14^{\text {bcd }}$ & $17.80^{\mathrm{a}}$ \\
\hline $1250 \mathrm{ppb} 1-\mathrm{MCP}+\mathrm{MAP}$ & 18.87 & $17.44^{\mathrm{bc}}$ & $17.39^{\mathrm{bcd}}$ & $16.82^{\text {cde }}$ & $17.21^{\mathrm{b}}$ \\
\hline Storage Period means & & $18.18^{\mathrm{A}}$ & $17.12^{\mathrm{B}}$ & $16.41^{\mathrm{C}}$ & \\
\hline LSD $(\mathrm{P}<0.05)$ & \multicolumn{4}{|c|}{0.6643} & \multirow{2}{*}{0.4763} \\
\hline $\mathrm{LSD}_{\text {Int }}(\mathrm{P}<0.05)$ & & & & & \\
\hline
\end{tabular}

Values in the same column and raw followed by different small and capital letters are significantly different $(\mathrm{P}<0.05)$ by LSD., N.S.: Not significant.

Table 3 Effects of application and storage periods on total soluble solids (\%)

\begin{tabular}{|c|c|c|c|c|c|}
\hline \multirow{2}{*}{ Aplications } & \multicolumn{4}{|c|}{ Storage Periods } & \multirow{2}{*}{$\begin{array}{c}\text { Application } \\
\text { means }\end{array}$} \\
\hline & Harvest & 40 days & 80 days & 120 days & \\
\hline Control & 17.19 & $16.80^{\mathrm{ab}}$ & $17.72^{\mathrm{a}}$ & $16.59^{\mathrm{abc}}$ & 17.03 \\
\hline $625 \mathrm{ppb} 1-\mathrm{MCP}$ & 17.19 & $17.15^{\mathrm{ab}}$ & $17.55^{\mathrm{ab}}$ & $16.62^{\mathrm{abc}}$ & 17.10 \\
\hline $1250 \mathrm{ppb} 1-\mathrm{MCP}$ & 17.19 & $16.61^{\mathrm{abc}}$ & $16.87^{\mathrm{ab}}$ & $16.39^{b c}$ & 16.62 \\
\hline MAP & 17.19 & $17.45^{\mathrm{ab}}$ & $16.79^{\mathrm{ab}}$ & $15.47^{\mathrm{c}}$ & 16.57 \\
\hline $625 \mathrm{ppb} 1-\mathrm{MCP}+\mathrm{MAP}$ & 17.19 & $16.78^{\mathrm{ab}}$ & $17.05^{\mathrm{ab}}$ & $16.90^{\mathrm{ab}}$ & 16.91 \\
\hline $1250 \mathrm{ppb} 1-\mathrm{MCP}+\mathrm{MAP}$ & 17.19 & $17.55^{\mathrm{ab}}$ & $17.39^{\mathrm{ab}}$ & $16.48^{\mathrm{bc}}$ & 17.14 \\
\hline Storage Periods means & & $17.05^{\mathrm{A}}$ & $17.22^{\mathrm{A}}$ & $16.40^{\mathrm{B}}$ & N.S. \\
\hline LSD $(\mathrm{P}<0.05)$ & \multirow{2}{*}{\multicolumn{4}{|c|}{$\begin{array}{l}0.2710 \\
1.2341\end{array}$}} & 07553 \\
\hline $\mathrm{LSD}_{\text {Int }}(\mathrm{P}<0.05)$ & & & & & 0.1555 \\
\hline
\end{tabular}

Values in the same column and raw followed by different small and capital letters are significantly different (P<0.05) by LSD., N.S.: Not significant.

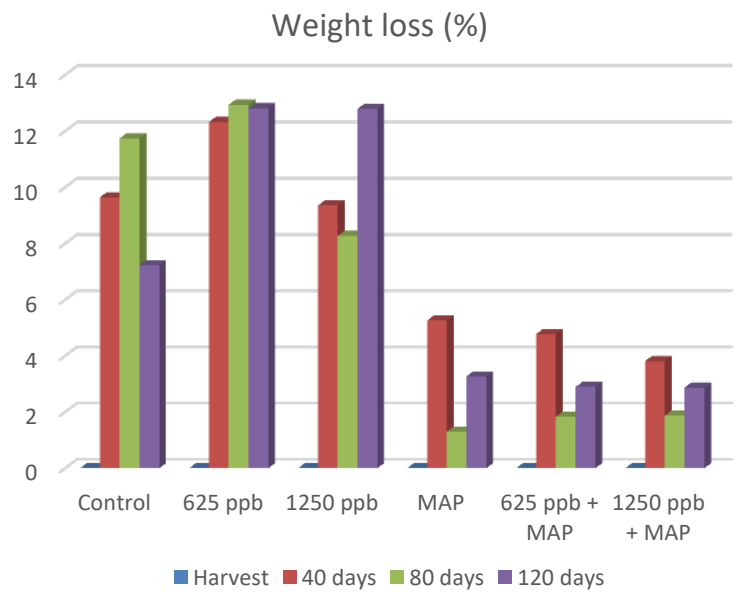

Figure 1 Weight loss $(\%)$
TSS (\%)

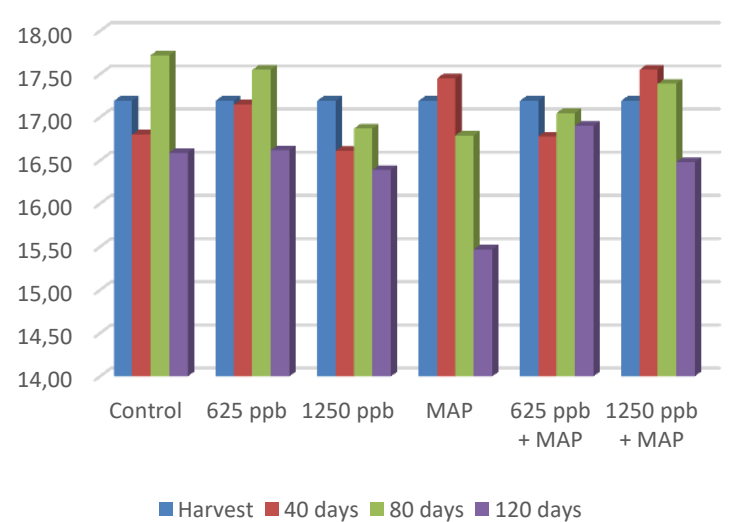

Figure 2 Total soluble solids (\%) 
Table 4 Effects of application and storage periods on titratable total acidty (\%)

\begin{tabular}{|c|c|c|c|c|c|}
\hline \multirow{2}{*}{ Aplications } & \multicolumn{4}{|c|}{ Storage Periods } & \multirow{2}{*}{$\begin{array}{c}\text { Application } \\
\text { means }\end{array}$} \\
\hline & Harvest & 40 days & 80 days & 120 days & \\
\hline Control & 0.1259 & $0.0755^{\mathrm{b}}$ & $0.0712^{\mathrm{b}}$ & $0.0891^{\mathrm{ab}}$ & 0.0786 \\
\hline $625 \mathrm{ppb} 1-\mathrm{MCP}$ & 0.1259 & $0.0996^{\mathrm{a}}$ & $0.0723^{\mathrm{b}}$ & $0.0709^{\mathrm{b}}$ & 0.0809 \\
\hline 1250 ppb $1-\mathrm{MCP}$ & 0.1259 & $0.0742^{\mathrm{b}}$ & $0.0719^{\mathrm{b}}$ & $0.0681^{\mathrm{b}}$ & 0.0714 \\
\hline MAP & 0.1259 & $0.0847^{\mathrm{ab}}$ & $0.0732^{\mathrm{b}}$ & $0.0701^{\mathrm{b}}$ & 0.0760 \\
\hline $625 \mathrm{ppb} 1-\mathrm{MCP}+\mathrm{MAP}$ & 0.1259 & $0.0813^{\mathrm{ab}}$ & $0.0733^{\mathrm{b}}$ & $0.0724^{\mathrm{b}}$ & 0.0756 \\
\hline $1250 \mathrm{ppb} 1-\mathrm{MCP}+\mathrm{MAP}$ & 0.1259 & $0.0725^{\mathrm{b}}$ & $0.0713^{\mathrm{b}}$ & $0.0691^{\mathrm{b}}$ & 0.0709 \\
\hline Storage Periods means & & $0.0813^{\mathrm{A}}$ & $0.0722^{\mathrm{B}}$ & $0.0732^{\mathrm{B}}$ & N.S. \\
\hline LSD $(\mathrm{P}<0.05)$ & \multicolumn{4}{|c|}{0.0053} & \\
\hline $\operatorname{LSD}_{\text {Int }}(\mathrm{P}<0.05)$ & \multicolumn{4}{|c|}{0.0232} & \\
\hline
\end{tabular}

Table 5 Effects of application and storage periods on $\mathrm{pH}$ value

\begin{tabular}{|c|c|c|c|c|c|}
\hline \multirow{2}{*}{ Aplications } & \multicolumn{4}{|c|}{ Storage Periods } & \multirow{2}{*}{$\begin{array}{l}\text { Application } \\
\text { means }\end{array}$} \\
\hline & Harvest & 40 days & 80 days & 120 days & \\
\hline Control & 2.56 & $2.84^{\mathrm{ef}}$ & $2.75^{\mathrm{f}}$ & $3.77^{\mathrm{a}}$ & $3.12^{\mathrm{B}}$ \\
\hline $625 \mathrm{ppb} 1-\mathrm{MCP}$ & 2.56 & $2.91^{\mathrm{e}}$ & $2.91^{\mathrm{e}}$ & $3.27^{\mathrm{c}}$ & $3.03^{\mathrm{C}}$ \\
\hline $1250 \mathrm{ppb} 1-\mathrm{MCP}$ & 2.56 & $2.75^{\mathrm{f}}$ & $2.91^{\mathrm{e}}$ & $3.71^{\mathrm{a}}$ & $3.12^{\mathrm{B}}$ \\
\hline MAP & 2.56 & $2.81^{\mathrm{f}}$ & $3.12^{\mathrm{d}}$ & $3.74^{\mathrm{a}}$ & $3.22^{\mathrm{A}}$ \\
\hline $625 \mathrm{ppb} 1-\mathrm{MCP}+\mathrm{MAP}$ & 2.56 & $2.81^{\mathrm{f}}$ & $3.11^{\mathrm{d}}$ & $3.43^{\mathrm{b}}$ & $3.11^{\mathrm{B}}$ \\
\hline $1250 \mathrm{ppb} 1-\mathrm{MCP}+\mathrm{MAP}$ & 2.56 & $2.78^{f}$ & $3.22^{\mathrm{c}}$ & $3.39^{\mathrm{b}}$ & $3.13^{\mathrm{B}}$ \\
\hline Storage Periods means & & $2.81^{\mathrm{C}}$ & $3.00^{\mathrm{B}}$ & $3.55^{\mathrm{A}}$ & \\
\hline LSD $(\mathrm{P}<0.05)$ & \multicolumn{4}{|c|}{0.0293} & \multirow{2}{*}{0.0586} \\
\hline $\operatorname{LSD}_{\text {Int }}(\mathrm{P}<0.05)$ & \multicolumn{4}{|c|}{0.0965} & \\
\hline
\end{tabular}

Values in the same column and raw followed by different small and capital letters are significantly different (P<0.05) by LSD., N.S.: Not significant.

Table 6 Effects of application and storage periods on decay ratio (\%)

\begin{tabular}{|c|c|c|c|c|c|}
\hline \multirow{2}{*}{ Aplications } & \multicolumn{4}{|c|}{ Storage Periods } & \multirow{2}{*}{$\begin{array}{c}\text { Application } \\
\text { means }\end{array}$} \\
\hline & Harvest & 40 days & 80 days & 120 days & \\
\hline Control & 0 & $3.00^{\mathrm{d}}$ & $9.60^{b}$ & $16.20^{\mathrm{a}}$ & $9.60^{A}$ \\
\hline $625 \mathrm{ppb} 1-\mathrm{MCP}$ & 0 & $0^{\mathrm{e}}$ & $2.99^{d}$ & $2.96^{\mathrm{d}}$ & $1.98^{\mathrm{D}}$ \\
\hline $1250 \mathrm{ppb} 1-\mathrm{MCP}$ & 0 & $2.99^{\mathrm{d}}$ & $9.41^{\mathrm{b}}$ & $9.38^{\mathrm{b}}$ & $7.26^{\mathrm{B}}$ \\
\hline MAP & 0 & $0^{\mathrm{e}}$ & $0^{\mathrm{e}}$ & $2.99^{\mathrm{d}}$ & $0.99^{\mathrm{E}}$ \\
\hline $625 \mathrm{ppb} 1-\mathrm{MCP}+\mathrm{MAP}$ & 0 & $0^{\mathrm{e}}$ & $0^{\mathrm{e}}$ & $2.97^{\mathrm{d}}$ & $0.99^{\mathrm{E}}$ \\
\hline $1250 \mathrm{ppb} 1-\mathrm{MCP}+\mathrm{MAP}$ & 0 & $3.11^{\mathrm{d}}$ & $6.23^{\mathrm{c}}$ & $9.64^{\mathrm{b}}$ & $6.32^{\mathrm{C}}$ \\
\hline Storage Periods means & 0 & $1.51^{\mathrm{C}}$ & $4.70^{\mathrm{C}}$ & $7.35^{\mathrm{A}}$ & \\
\hline LSD $(\mathrm{P}<0.05)$ & & 07829 \\
\hline $\mathrm{LSD}_{\text {Int }}(\mathrm{P}<0.05)$ & \multicolumn{3}{|c|}{1.2845} & & 0.1829 \\
\hline
\end{tabular}

Titratable total acidity (TTA): Titratable acidity is an indicator of metabolic activity of the fruits and decreases were observed in TA values throughout the storage durations (Figure 3 and Table 3). The value at harvest was measured as $0.1259 \% \mathrm{~g}$ and a rapid decrease was observed in all treatments during the initial phase of storage (40-day), the values had a decreasing trend also in the other storage periods, but the decreases were slowed down with the treatments. Similar decreases in TTA values throughout the storage durations were also reported by Yazic1 et al. (2005). Preservation of TTA throughout the storage is a significant issue for efficient preservation of fruit metabolism, taste, aroma and smell. In this study, it was observed that $625 \mathrm{ppb} 1-\mathrm{MCP}$ treatment was found to be effective in preserving TTA levels during the initial phase of storage (40-day). In longer storage durations, this treatment also had similar TTA values with the other treatments. The $1250 \mathrm{ppb} 1$ MCP and $1250 \mathrm{ppb} 1-\mathrm{MCP}+\mathrm{MAP}$ treatments were identified as the most stable treatments in preservation of TTA level of the fruits in all storage durations.

$p H$ : The decreasing TTA values reflected as increasing $\mathrm{pH}$ values. Increasing $\mathrm{pH}$ values were observed in all treatments with the progress of storage durations and the $625 \mathrm{ppb} 1-\mathrm{MCP}, 625 \mathrm{ppb} 1-\mathrm{MCP}+\mathrm{MAP}$ and $1250 \mathrm{ppb} 1-\mathrm{MCP}+\mathrm{MAP}$ treatments were able to best suppress $\mathrm{pH}$ values (Figure 4 and Table 4). The $1250 \mathrm{ppb}$ 1-MCP and MAP treatments were able to provide an efficient preservation in $\mathrm{pH}$ values during the $1^{\text {st }}$ (40-day) and the $2^{\text {nd }}$ stage (80-day) storage, but the relevant treatments were not able to provide the same effect in $3^{\text {rd }}$ phase (120-day) storage and $\mathrm{pH}$ levels of the fruits ultimately reached to $\mathrm{pH}$ level of control fruits.

Grain color: The changes observed in seed colors with storage durations and treatments are presented in Figure 5 and Table 5. While remarkable significant decreases were observed in control, $625 \mathrm{ppb}$ and 1250 $\mathrm{ppb} 1-\mathrm{MCP}$ treatments with the progress of storage 
durations, the decrease in color values was less in MAP and 1-MCP + MAP treatments. The MAP and $625 \mathrm{ppb}+$ MAP treatments yielded the best outcomes for the preservation of color values. There were remarkable differences between the color values of 625 and $1250 \mathrm{ppb}$ doses of 1-MCP treatments especially for 40 and 120-day storage durations and $625 \mathrm{ppb}$ dose of 1-MCP was found to be more suitable for the preservation of grain color. As being less remarkable, a similar case was also valid for $625 \mathrm{ppb}+$ MAP and $1250 \mathrm{ppb}+$ MAP treatments.

Decay ratio: With the progress of storage duration, some physiological disorders such as rotting, browning in peel and fruit flesh was observed in fruits. Visual physiological disorders were proportioned to number of fruits in relevant replication and presented in Figure 6 and Table 6. Decay ratios increased in control, $1250 \mathrm{ppb} 1$ MCP, $1250 \mathrm{ppb} 1-\mathrm{MCP}+\mathrm{MAP}$ treatments and such increases in $625 \mathrm{ppb} 1$-MCP treatments were found to be significant for 80 and 120-day storage durations. At the end of 120-day storage duration, remarkable perish ratios were observed in MAP and $625 \mathrm{ppb} 1-\mathrm{MCP}+\mathrm{MAP}$ treatments. The MAP and $625 \mathrm{ppb} 1-\mathrm{MCP}+\mathrm{MAP}$ treatments provided the best protection against rotting and perish in both short and long storage durations. As it was reported by $\mathrm{Oz}$ and Ulukanl 1 (2011), low $\mathrm{O}_{2}$ and relatively high $\mathrm{CO}_{2}$ levels minimized physiological disorders in fruits.

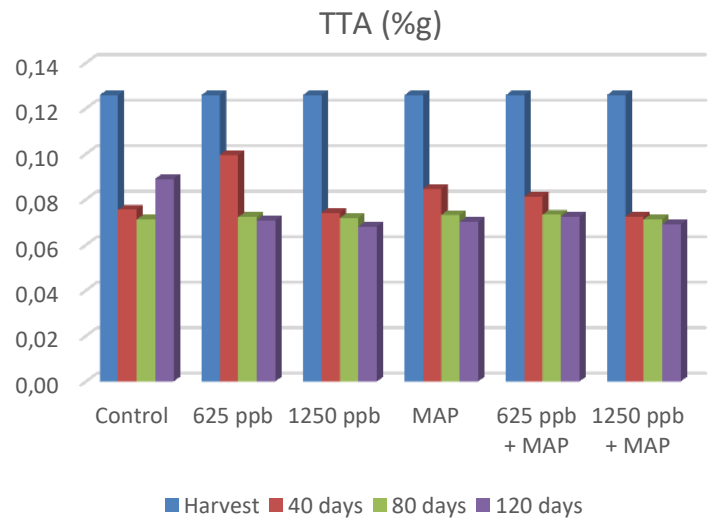

Figure 3 Titratable total acidity (\%g)

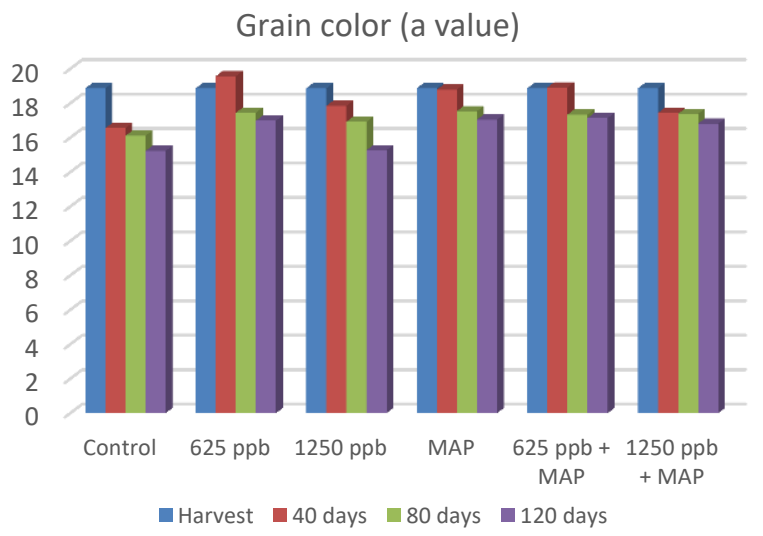

Figure 5 Grain color (a values)

\section{Conclusion}

With regard to weight loss throughout the storage durations, remarkable preservative effects of MAP treatments can clearly be seen. Although combined 1MCP + MAP treatments yielded close values, they were placed in different statistical group.

The treatments best preserving TSS composition of the fruits throughout the storage durations were identified as 625ppb 1-MCP + MAP and $1250 \mathrm{ppb} 1-\mathrm{MCP}$ treatments. For short and long storage durations, $625 \mathrm{ppb}$ $1-\mathrm{MCP}+\mathrm{MAP}$ and $1250 \mathrm{ppb} 1-\mathrm{MCP}$ treatments were found to be appropriate and MAP treatments seemed to be appropriate alternative for short and medium storage durations.

Considering TTA, $\mathrm{pH}$ and grain color parameters, it was observed that MAP, 625 ppb 1-MCP and 625 ppb 1-

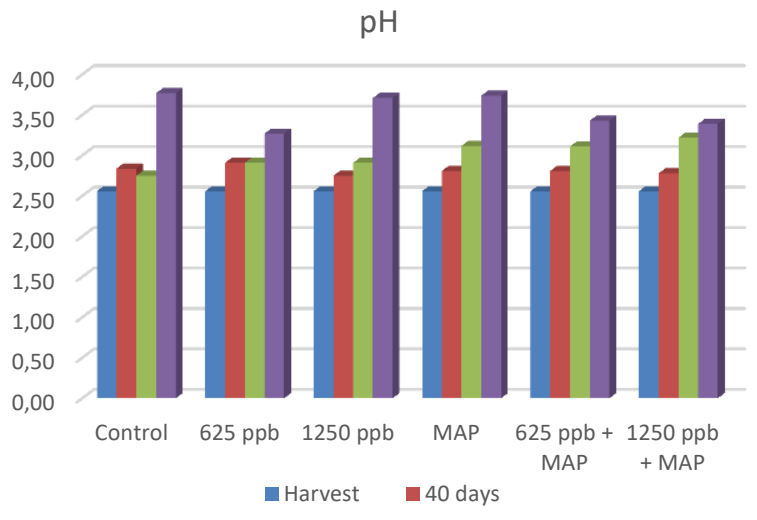

Figure $4 \mathrm{pH}$ value

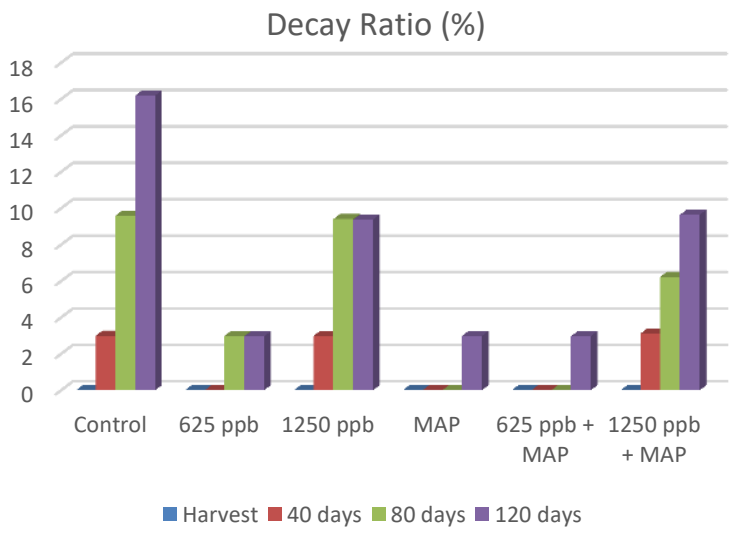

Figure 6 Decay ratio (\%)

MCP + MAP treatments were appropriate alternatives for short, medium and long storage durations.

To minimize decay ratio, $625 \mathrm{ppb} 1-\mathrm{MCP}$ treatments were considered as appropriate alternatives for short storage durations; $625 \mathrm{ppb} 1-\mathrm{MCP}+\mathrm{MAP}$ and MAP treatments were considered as appropriate alternatives for medium and long storage durations.

\section{References}

Anonymous. 2013. Mark's fruit crops. Web site. http://www.fruit-crops.com/pomegranate-punica-granatum1/ Access date: 15.3.2013.

Blankenship S. 2001. Ethylene Effects and the Benefits of 1MCP. Horticultural Science North Carolina State University. Raleigh. NC. Perishables Handling Quarterl, Issue No:108, p. 2-4. 
Kader AA, Chordas A, Elyatem S. 1984. Responses on Pomegranates to Ethylene Treatment and Storage Temperature. California Agriculture. July-August, 14-15.

Kader AA, Zagory D, Kerbel EL. 1989. Modified atmosphere packaging of fruits and vegetables. Critical Reviews in Food Science Nutrition. 28: 1- 30

Karaçalı İ. 2009. Bahçe ürünlerinin muhafazası ve Pazarlanması. Ege Üniversitesi Ziraat Fakültesi Yayınları No: 494, Bornova, İzmir. s. 486.

Nanda S, Sudhakar Rao DV, Krishnamurthy S., 2001. Effect of Shrink Film Wrapping and Storage Temperature on the Shelf Life and Quality of Pomegranate Fruits cv. Ganesh. Postharvest Biology and Technology 22 (1): 61-69.

Özgüven AI, Yılmaz C. 2000. Pomegranate Growing in Turkey. In: Melgarejo P. (ed.), Martínez-Nicolás J.J. (ed.), MartínezTomé J. (ed.). Production, processing and marketing of pomegranate in the Mediterranean region: Advances in research and technology. Zaragoza: CIHEAM, 2000. p. 4148 (Options Méditerranéennes: Série A. Séminaires Méditerranéens; n. 42).

Özdemir M. 2001. Mathematical analysis of color changes and chemical parameters of roasted hazelnuts. Ph.D. Thesis. Istanbul Technical University, $161 \mathrm{pp}$.
Renwick A, Leblanc JC, Setzer RW. 2010. Application of the margin of exposure (MoE) approach to substances in food that are genotoxic and carcinogenic - Example: 1Methylcyclopropene and its impurities (1-chloro-2methylpropene and 3-chloro-2-methylpropene). Food and Chemical Toxicology. (48): 81-88.

Sisler EC, Serek M. 1997. Inhibitors of ethylene responses in plants at the receptor level: recent developments. Physiologia Plantarum, 100: 577-582.

Sisler EC, Serek M. 1999. Bot. Bull. Acad. Sin. Compounds controlling the ethylene receptor. 40: 1-7.

Sivertsvik M, Jeksrud WK, Rosnes JT. 2002 A review of modified atmosphere packaging of fish and fishery products - significance of microbial growth, activities and safety. International Journal of Food Science and Technology 2002, 37: $107-127$

Taiz L, Zeiger E. 2008. Bitki Fizyolojisi. Palme Yayınları: 455. Etilen Gaz Formundaki Hormon (Bölüm: 22). 531-538.

Yazıcı K, Karaşahin I, Şahin G, Erkan M, Kaynak L. 2005. Kaolin Uygulamaları İle Modifiye Atmosfer (MA) Koşullarının Nar Muhafazası Üzerine Etkileri. 3. Bahçe Ürünlerinde Muhafaza ve Pazarlama Sempozyumu. 6-9 Eylül 2005, 235-243. Antakya-Hatay. 